\title{
26. SULFUR ISOTOPE RECONNAISSANCE OF EPIGENETIC PYRITE IN OCEAN-FLOOR BASALTS, LEG 34 AND ELSEWHERE
}

\author{
Cyrus W. Field, ${ }^{1}$ Jack R. Dymond, ${ }^{2}$ G. Ross Heath, ${ }^{2}$ John B. Corliss, ${ }^{2}$ and E. Julius Dasch ${ }^{1}$
}

\begin{abstract}
Sulfur isotope analyses of 10 epigenetic occurrences of pyrite in ocean-floor basalts yield an unexpectedly large range of $\delta^{34} \mathrm{~S}$ values (from -24.2 to $+23.0^{\circ} / 00$ ) for sulfides that are inferred to be of hydrothermal origin. The existing geologic, mineralogical, and isotopic data do not permit an unambiguous interpretation of the chemical and thermal characteristics of these hydrothermal systems. They fit either of two hypothetical models that assume isotopic equilibration between varying proportions of oxidized and reduced species of sulfur, but with pyrite deposition either (1) at $150^{\circ} \mathrm{C}$ and less from an infinite reservoir of heavy $\left(+21 \%\right.$ oo seawater sulfur, or $(2)$ at $300^{\circ} \mathrm{C}$ and less from a finite reservoir of deep-seated $(0 \% \% 0)$ "magmatic" sulfur. Further detail and elaboration of these or alternative models must await additional mineralogical and isotopic studies, particularly of coexisting hydrothermal assemblages.
\end{abstract}

\section{INTRODUCTION}

Sulfur isotope compositions have been determined for epigenetic occurrences of pyrite in four samples of ocean-floor basalt cored from basement rocks during the Leg 34 cruise. These and other sulfur isotope abundance data described herein are reported as conventional $\delta^{34} \mathrm{~S}$ per mil values. The positive or negative per mil $(\% 00)$ values denote enrichment or depletion of ${ }^{34} \mathrm{~S}$ in the sample, in parts per thousand, relative to the meteoritic sulfur standard $\left(0^{\circ} / 00\right.$ by definition). Concentration of sulfides, extraction of sulfur as sulfur dioxide, and the isotopic analyses of sulfur were performed by conventional methods. The total error for these analyses, expressed as a standard deviation, is approximately $0.2 \%$.

The sulfur isotope analyses were performed on small quantities of pyrite extracted from the following basalt samples of Leg 34: 319A-3-1, 73-78 cm (-14.10\%); 319A$3-1,98-100 \mathrm{~cm}\left(+23.0^{\circ} / 00\right) ; 321-14-1,39-42 \mathrm{~cm}$ $(+2.0 \%$ oo); and $321-14-3,92-100 \mathrm{~cm}(-1.1 \% \% 0)$. These analyses are similar to data (unpublished) we have obtained for epigenetic pyrite in ocean-floor basalts from other localities in and adjacent to the Pacific Ocean basin. The pyrites are from two Leg 16 core samples from the Carnegie $(157-49-2,90-93 \mathrm{~cm} ;-24.2 \%)$ and Cocos $(158-36-1,147 \mathrm{~cm} ;-15.5 \%$ \%o ridges, respectively; a dredge-haul sample from the Juan de Fuca Ridge (1X; $-5.6 \%$ of of the northeast Pacific Ocean; and two samples of the Eocene Siletz River Volcanics (SV-1, -17.4\% \% ; and SV-2, $+14.2 \%$ ) from outcrops in the central Coast Range Mountains of western Oregon.

\footnotetext{
'Department of Geology, Oregon State University, Corvallis, Oregon.

${ }^{2}$ School of Oceanography, Oregon State University, Corvallis, Oregon.
}

The distribution of $\delta^{34} \mathrm{~S}$ per mil values for epigenetic occurrences of pyrite in ocean-floor basalts is graphically summarized in Figure 1. For the purposes of comparison, $\delta^{34} \mathrm{~S}$ data for the range and mean of sulfate and sulfide minerals of other geologically important environments are also illustrated. The number of samples analyzed is given in parentheses to the right of each deposit or sample group. Vertical lines at 0 and $+21 \%$, shown in Figure 1, mark the $\delta^{34} \mathrm{~S}$ compositions of deepseated "magmatic or mantle" sulfides and modern seawater sulfate (Holser and Kaplan, 1966; Claypool et al., 1972), respectively.

\section{HOST ROCKS AND OCCURRENCE OF PYRITE}

Occurrences of epigenetic pyrite described in this report are exclusively confined to ocean-floor basalts. Detailed studies of samples from the Juan de Fuca Ridge (Kay et al., 1970); Siletz River Volcanics (Snavely et al., 1968); Carnegie and Cocos ridge sites of DSDP Leg 16 (Yeats et al., 1973); and elsewhere indicate that the basaltic host rocks have close similarities in texture, mineralogy, and chemistry. Although the basalts are predominantly tholeiites, samples from Leg 34 may have affinities to alkali olivine basalts according to Hart et al. (1974). Petrographic investigations by the previously cited authors and ourselves indicate the host rocks to be hypocrystalline, fine grained to microcrystalline, and commonly microporphyritic. The primary mineral constituents are chiefly plagioclase feldspar (labradorite), clinopyroxene (augite), and relatively large amounts (up to $15 \%$ ) of opaque iron-titanium oxides. The opaque minerals occur as disseminated euhedra, subhedra, and skeletal growths of magnetite and probably ilmenite that impart a moderate magnetic response to the samples. Smectite, as fibrous masses and felty mosaics, is variably abundant as an alteration product of glass or as a minor 


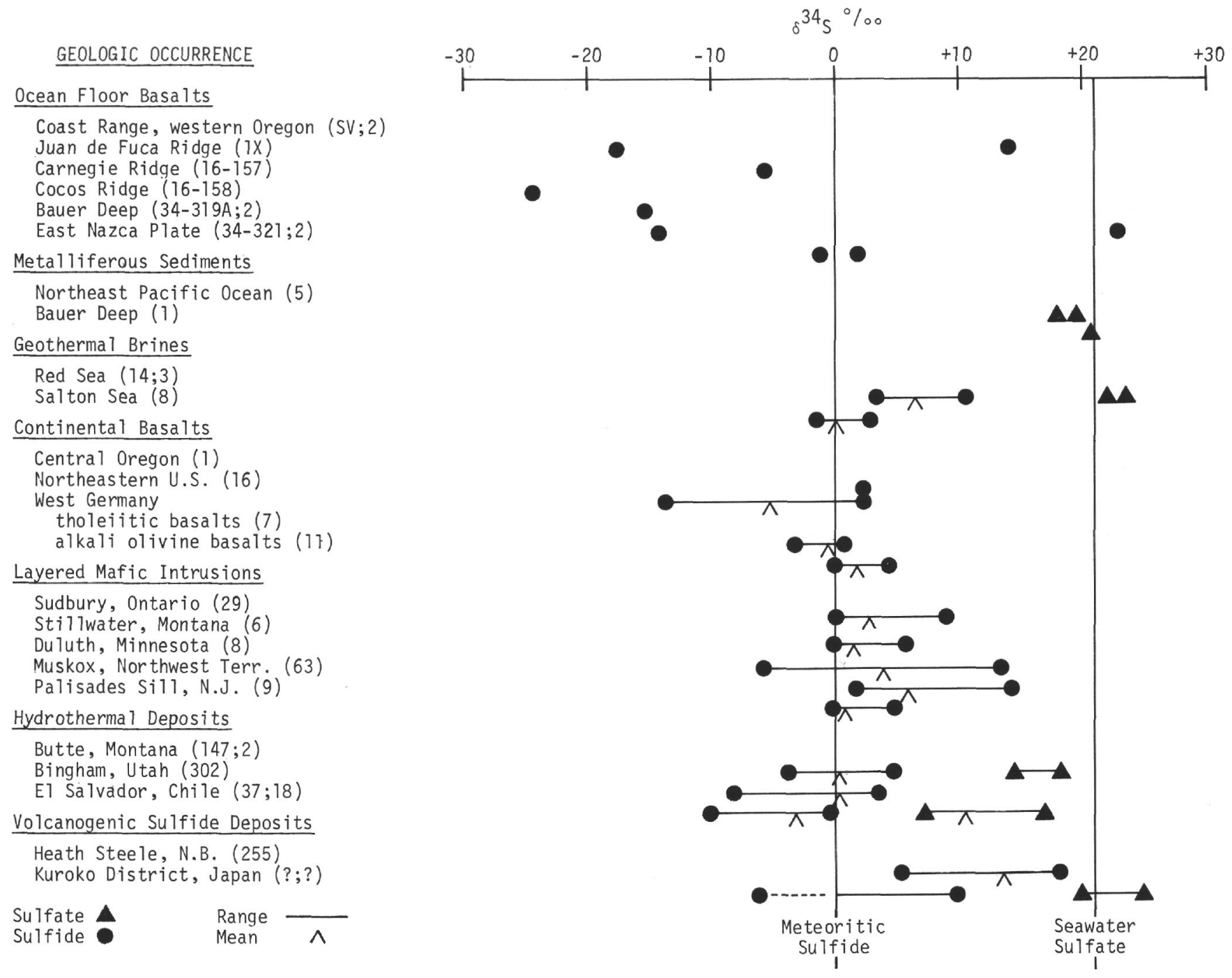

Figure 1. Distribution of $\delta{ }^{34} S^{\circ} \% \circ$ for samples from various geological settings.

selective replacement of feldspar and pyroxene. Gangue minerals such as carbonate, epidote, magnetite, zeolite, and pyrite form infrequent secondary cavity fillings of fractures, veinlets, and vesicles.

Sulfides in the basaltic host rocks exhibit two principal modes of occurrence. One mode consists of trace amounts of finely disseminated and microcrystalline blebs of iron-copper sulfides including pyrite and probably pyrrhotite and chalcopyrite that are clearly syngenetic (magmatic) in origin. Extraction and analysis of these sulfides was impossible because of their sparse distribution (less than $0.01 \%$ by volume), disseminated and microcrystalline habit, and the small sizes of samples available for study. The other and megascopically predominant form of sulfide consists of pyrite localized as late epigenetic fillings of fractures, veinlets, and vesicles. Isotopic analyses of these sulfide occurrences are representative of finely crystalline pyrite in thin veinlets (Samples 1X; 16-157; 34-319A-3-1, 73-78 cm); globular fillings of vesicles adjacent to veinlets (Sample 34-321-14-1, 39-42 cm); and medium to finely crystalline pyrite euhedra occurring disseminated or in nodular clusters on fracture surfaces or within gouge zones (Samples SV-1; SV-2; 16-158; 34-319A-3-1, 98-100 cm;
34-321-14-3, 92-100 cm). Although megascopically discernible where present, the occurrences of epigenetic pyrite are infrequent and of local distribution. With the exception of Samples 1X, SV-2, and 16-157, in which pyrite was moderately abundant and comprised as much as $1 \%$ or $2 \%$ of the host rock by volume, the total quantity of sulfide present and extracted for analysis was usually 20 to $30 \mathrm{mg}$ or less. Examination of hand specimens and petrographic study of thin and polished sections do not suggest any obvious correlation between sulfides and the presence of other gangue minerals in veinlets, the intensity of smectite alteration, or the hydrothermal destruction of primary iron-titanium oxides in the host rocks. Thus, sulfide deposition was apparently independent of veining by nonmetallic gangue minerals, although similarly controlled by structure, and was compatible with the chemical stability of primary oxide phases in the basaltic host rocks.

\section{DISCUSSION AND INTERPRETATION}

The epigenetic pyrites of ocean-floor basalts exhibit an unexpected and remarkably large isotopic variation. As previously noted, the $\delta^{34} \mathrm{~S}$ values range from -24.2 to $+23.0 \%$ for a total isotopic variation of $47.2 \%$ (or 
4.7\%). In Hole 319A, for example, the isotopic range for pyrite in two nearby samples (less than $28 \mathrm{~cm}$ apart) is $37.1 \%$, alone. Extreme isotopic variability is rarely noted in sulfides formed at intermediate to high temperatures $\left(250^{\circ} \mathrm{C}\right.$ and higher $)$ in association with hydrothermal or magmatic processes. These large isotopic variations are more typical of low temperature biogenic fractionation $\left(-62\right.$ to $\left.+49^{\circ} \% 0\right)$ that localize syngeneticdiagenetic pyrite in sediments and sedimentary rock (Jensen et al., 1960; Kaplan et al., 1963). However, geologic evidence and other considerations would seemingly preclude the biogenic agents as a likely process for localizing pyrite in the ocean-floor basalts.

The sulfur isotope data for several geologic environments, as summarized in Figure 1, are closely grouped about the $0 \%$ value of meteoritic sulfur and which, accordingly, suggest a deep-seated source for the sulfur. These samples include sulfides from the Salton Sea brine (White, 1968); sulfides in continental basalts from central Oregon (unpublished data), the Triassic Newark Group of the northeastern U.S. (Smitheringale and Jensen, 1963), and West Germany (Schneider, 1970); sulfides from layered mafic intrusions of Sudbury, Ontario (Thode et al., 1962), the Stillwater Complex, Montana (Thode et al., 1962; Smitheringale and Jensen, 1963), the Duluth Gabbro, Minnesota, the Palisades Sill, New Jersey (Smitheringale and Jensen, 1963), and the feeder dike and layered series of the Muskox Intrusion, Northwest Territories (Sasaki, 1969); and both sulfide and sulfate minerals from hydrothermal deposits such as Butte, Montana (Lange and Cheney, 1971; unpublished data), Bingham, Utah (Field and Moore, 1971), and El Salvador, Chile (Gustafson and Field, in preparation). For sulfides in the ocean-floor basalts, only those from Site $321(+2.0$ and $-1.1 \%$ ) and possibly dredge-haul Sample 1X from the Juan de Fuca Ridge $(-5.6 \%$ oo $)$ exhibit $\delta^{34} \mathrm{~S}$ values similar to that of meteoritic sulfur. In contrast, sulfur-bearing minerals from other environments are markedly enriched in ${ }^{34} \mathrm{~S}$ and these data, together with geologic and other evidence, indicate a source of heavy sulfur from seawater or possibly sedimentary evaporites. Such deposits (see Figure 1) include sulfates in the metalliferous sediments (Dymond et al., 1973); and sulfates and sulfides in sediments of the Red Sea Basin (Kaplan et al., 1969) and in volcanogenic massive sulfide deposits at Heath Steele, New Brunswick (Dechow, 1960; Lusk and Crocket, 1969), and in the Kuroko District, Japan (Aoki et al., 1970; Ohmoto et al., 1970).

The extremely broad range of $\delta^{34} \mathrm{~S}$ values (from -24.2 to $+23.0 \%$ ) for epigenetic pyrites of the ocean-floor basalts is larger than that of all other geologically diverse environments summarized in Figure 1. Because the pyrite data range from strong ${ }^{34} \mathrm{~S}$-depletion relative to deep-seated "magmatic" sulfur $\left(0^{\circ} \% 0\right)$ to weak ${ }^{34} \mathrm{~S}$ enrichment relative to modern seawater sulfate $(+21 \%$ ) , interpretations of the pyrite data relative to possible sources of sulfur must obviously be more complex than a straightforward consideration of the two geologically reasonable and isotopically distinctive endmember sources, or mixtures thereof, would indicate. Recent elaboration of sulfur isotope fractionation theory by Sakai (1968) and Ohmoto (1972) has demonstrated that under equilibrium conditions the $\delta^{34} \mathrm{~S}$ content of a hydrothermal sulfide is a function not only of temperature and the isotopic composition of total sulfur in the system, but also of parameters such as acidity $(p \mathrm{H})$ and oxygen fugacity (Eh), which in turn control the kinds and proportions of the various sulfur species, and the total amount of sulfur in the reservoir. Isotopic effects imposed by nonequilibrium (unidirectional) reactions are more difficult to evaluate as they require a knowledge of reactants and products, the composition and supply of total sulfur in the reservoir, temperature, and mineral paragenesis. Because of uncertainties as to the extent to which these reactions may be of importance, if at all, the interpretations that follow will assume conditions of isotopic equilibrium.

On the basis of established fractionation theory, the available isotopic data impose constraints on speculations concerning the depositional environment and source of sulfur for the epigenetic pyrites of ocean-floor basalts. For example, equilibration of pyrite with aqueous species of sulfide-sulfur $\left(\mathrm{H}_{2} \mathrm{~S}, \mathrm{HS}^{-}, \mathrm{S}^{2-}\right)$ could not have produced the observed isotopic range; regardless of source $\left({ }^{34} \mathrm{~S}\right.$-enriched seawater sulfate or $0 \%$ deep-seated sulfur) and (or) temperature of deposition. As a consequence, more complex processes of fractionation involving $p \mathrm{H}$, Eh, or a finite reservoir of sulfur in the hydrothermal system are required to explain the wide variations of the pyrite data.

Isotopic effects caused by variations in $p \mathrm{H}$ are probably negligible because the basaltic host rocks do not show evidence of hydrogen metasomatism, such as replacement by kaolinite or sericite. However, because ${ }^{34} \mathrm{~S}$ is preferentially concentrated in the more strongly bonded oxidized species of sulfur, variations in Eh with concomitant changes in the proportions of oxidized $\left(\mathrm{SO}_{2}, \mathrm{SO}_{4}{ }^{2-}\right)$ to reduced $\left(\mathrm{H}_{2} \mathrm{~S}, \mathrm{HS}^{-}, \mathrm{S}^{2-}\right)$ species of sulfur, as proposed by Sakai (1968) and Ohmoto (1972), might form sulfides variably depleted in ${ }^{34} \mathrm{~S}$ relative to that of total sulfur (source) in the system. The magnitude of this isotopic effect increases as the mole fraction of the oxidized species increases relative to that of the reduced species, and with diminishing temperature. Permissive evidence for an Eh-controlled isotopic effect in the ocean-floor basalts is the stability, and the possible formation, of the iron-titanium oxides during hydrothermal deposition of the pyrite. If it is assumed that the mole fraction of oxidized sulfur species ranged from more than 0.99 to less than 0.01 in the hydrothermal fluids, pyrite exhibiting the spectrum of measured $\delta^{34} \mathrm{~S}$ values $\left(-24\right.$ to $+23^{\circ} \% 0$ ) could have formed at temperatures of about $150^{\circ} \mathrm{C}$ and less, provided the system contained an infinite reservoir of sulfur and that it was compositionally heavy and similar to that of Cenozoic seawater sulfate $\left(+18\right.$ to $+25^{\circ} \% 0$; Holser and Kaplan, 1966). However, the validity of this model may be questioned on the basis of whether or not isotopic equilibrium could prevail at such low temperatures, and on the assumption of an infinite sulfur reservoir. Evidence for a possible finite supply of sulfur in the hydrothermal reservoir is suggested by the scarcity of sulfides throughout the basaltic host rocks and by their general 
absence as disseminated replacements of primary oxide and ferromagnesian minerals in the wall rocks adjacent to veinlets and fractures. With a finite reservoir of sulfur and with the wide range in the mole fractions of oxidized and reduced species of sulfur, as previously assumed, the measured isotopic variability of pyrite could be obtained via equilibrium reactions at temperatures of approximately $300^{\circ} \mathrm{C}$ or less, and from a source compositionally similar to deep-seated $(0 \%$ ) sulfur. Although both models have been inferred primarily on the basis of fractionation theory, the latter perhaps gives a more reasonable temperature range for hydrothermal deposition, and qualitatively it is in accord with the abundance and distribution of pyrite in the host rocks.

In conclusion, the available $\delta^{34} \mathrm{~S}$ data for epigenetic pyrite in ocean-floor basalts do not uniquely define the isotopic chemistry or thermal regime of sulfur in these hydrothermal systems. Provided a common genetic origin is assumed for these occurrences of epigenetic pyrite, the entire broad spectrum of $\delta^{34} \mathrm{~S}$ values $(-24.2$ to $+23.0^{\circ} / 00$ ) may be ascribed to hydrothermal deposition in either of two hypothetical systems. The sulfur in each system occurs as varying proportions of both oxidized and reduced species in isotopic equilibrium, but differs in terms of composition (source) and reservoir (quantity) configuration. Accordingly, the pyrites may have been deposited either from (1) an infinite reservoir of heavy $(+21 \%$ seawater sulfur at temperatures of $150^{\circ} \mathrm{C}$ and less, or from (2) a finite reservoir of deepseated $\left(0 \%\right.$ oo sulfur at temperatures of $300^{\circ} \mathrm{C}$ and less. Neither model precludes minor contamination by the other source of sulfur. However, more precise elaboration of the hydrothermal system must await additional data relevant to the epigenetic mineral assemblages, their paragenetic relationships, and especially to the isotopic compositions of any coexisting sulfate-sulfide or sulfide-sulfide phases that may be present.

\section{REFERENCES}

Aoki, K., Sato, T., Takeuchi, T., and Tatsumi, T., 1970. Kuroko deposits and Towada and Hakkoda Volcanoes: Internatl. Mineral. Assoc. and Int. Assoc. Genesis Ore Deposits, Guidebook 3, Tokyo-Kyoto Mtg.

Claypool, G.E., Holser, W.T., Kaplan, I.R., Sakai, H., and Zak, I., 1972. Sulfur and oxygen isotope geochemistry of evaporite sulfates: Geol. Soc. Am., Abstracts with Programs, v. 4, p. 473.

Dechow, E., 1960. Geology, sulfur isotopes and the origin of the Heath Steele ore deposits, Newcastle, N.B., Canada: Econ. Geol., v. 55, p. 539.

Dymond, J., Corliss, J.B., Heath, G.R., Field, C.W., Dasch, E.J., and Veeh, H.H., 1973. Origin of metalliferous sediments from the Pacific Ocean: Geol. Soc. Am. Bull., v. 84, p. 3355 .
Field, C.W. and Moore, W.J., 1971. Sulfure isotope study of the "B" Limestone and Galena Fissure ore deposits of the U.S. Mine, Bingham Mining District, Utah: Econ. Geol., v. 66, p. 48.

Hart, S.R., Yeats, R.S., Ade-Hall, J.M., Bass, M.N., Benson, W.E., Hart, R.A., Quilty, P.G., Sachs, H.M., Salisbury, M.H., and Vallier, T.L., 1974. Leg 34 oceanic basalt and the Nazca Plate: Geotimes, v. 19, p. 20.

Holser, W.T. and Kaplan, I.R., 1966. Isotope geochemistry of sedimentary sulfates: Chem. Geol., v. 1, p. 93.

Jensen, M.L., Field, C.W., and Nakai, N., 1960. Sulfur isotopes and the origin of sandstone-type uranium deposits: Biennial Progress Rept. 1959-1960, U.S. Atomic Energy Comm. Contract AT(30-1)-2261.

Kaplan, I.R., Emery, K.O., and Rittenberg, S.C., 1963. The distribution and isotopic abundance of sulphur in recent marine sediments off southern California: Geochim. Cosmochim. Acta, v. 27, p. 297.

Kaplan, I.R., Sweeney, R.E., and Nissenbaum, A., 1969. Sulfur isotope studies on Red Sea geothermal brines and sediments. In Degens, E.T. and Ross, D.A. (Eds.), Hot brines and recent heavy metal deposits in the Red Sea: New York (Springer-Verlag) p. 474.

Kay, R., Hubbard, N.J., and Gast, P.W., 1970. Chemical characteristics and origin of oceanic ridge volcanic rocks: J. Geophys. Res., v. 75, p. 1585.

Lange, I.M. and Cheney, E.S., 1971. Sulfur isotopic reconnaissance of Butte, Montana: Econ. Geol., v. 66, p. 63.

Lusk, J. and Crocket, J.H., 1969. Sulfur isotope fractionation in coexisitng sulfides from the Heath Steele B-1 Orebody, New Brunswick, Canada: Econ. Geol., v. 64, p. 147.

Ohmoto, H., 1972. Systematics of sulfur and carbon isotopes in hydrothermal ore deposits: Econ. Geol., v. 67, p. 551.

Ohmoto, H., Kajiwara, Y., and Date, J., 1970. The Kuroko ores in Japan; products of seawater?: Geol. Soc. Am. Abstract with Programs, v. 2, p. 640.

Sakai, H., 1968. Isotopic properties of sulfur compounds in hydrothermal processes: Geochem. J. (Japan), v. 2, p. 29.

Sasaki, A., 1969. Sulphur isotope study of the Muskox Intrusion, District of MacKenzie: Geol. Sur. Canada, Paper 6846.

Schneider, A., 1970. The sulfur isotope composition of basaltic rocks: Contrib. Mineral. Petrol., v. 25, p. 95.

Smitheringale, W.G. and Jensen, M.L., 1963. Sulfur isotopic composition of the Triassic igneous rocks of eastern United States: Geochim. Cosmochim. Acta, v. 27, p. 1183.

Snavely, P.D., Jr., MacLeod, N.S., and Wagner, H.C., 1968. Tholeiitic and alkalic basalts of the Eocene Siletz River Volcanics, Oregon Coast Range: Am. J. Sci., v. 266, p. 454.

Thode, H.G., Dunford, H.B., and Shima, M., 1962. Sulfur isotope abundances in rocks of the Sudbury District and their geological significance: Econ. Geol., v. 57, p. 565.

White, D.E., 1968. Environments of generation of some basemetal ore deposits: Econ. Geol., v. 63, p. 301.

Yeats, R.S., Forbes, W.C., Heath, G.R., and Scheidegger, K.F., 1973. Petrology and geochemistry of DSDP Leg 16 basalts, eastern equatorial Pacific. In van Andel, T.H., Heath, G. R., et al., Initial Reports of the Deep Sea Drilling Project, Volume 16: Washington (U.S. Government Printing Office), p. 617-640. 